\title{
Age of Unconformity within Tanjero Formation in Chwarta Area Northeast of Iraq (Kurdistan Region)
}

\author{
Khalid M. Sharbazheri \\ Department of Geology \\ Collage of Science \\ Sulaimani University
}

(Received 10/9/2006 , Accepted 21/1/2007)

\begin{abstract}
The age of the thick succession of 500m conglomerate and red claystone layers in the incised valleys at the lower part of Tanjero Formation at Chwarta area is estimated to be (1.23 m.y) duration. The age determination is achieved by Planktonic Foraminiferal biostratigraphic zonation which included the following Zones: Globotruncana aegyptiaca Interval Zone (CF8), Gansserina gansseri Interval Zone (CF7) Racemiguemblina fructicosa Interval Zone (CF4), Pseudoguembelina hariaensis Interval Zone (CF3) with missing zones of Contusotruncana contusa Interval zone (CF6) and Pseudotextularia intermedia Interval zone (CF5). Twenty six planktonic foraminiferal species and thirty benthonic foraminiferal species assigned to 33 genera have been recorded. The zonal scheme developed here is correlated with other sequences of Li and Keller (1998a) and discussed.
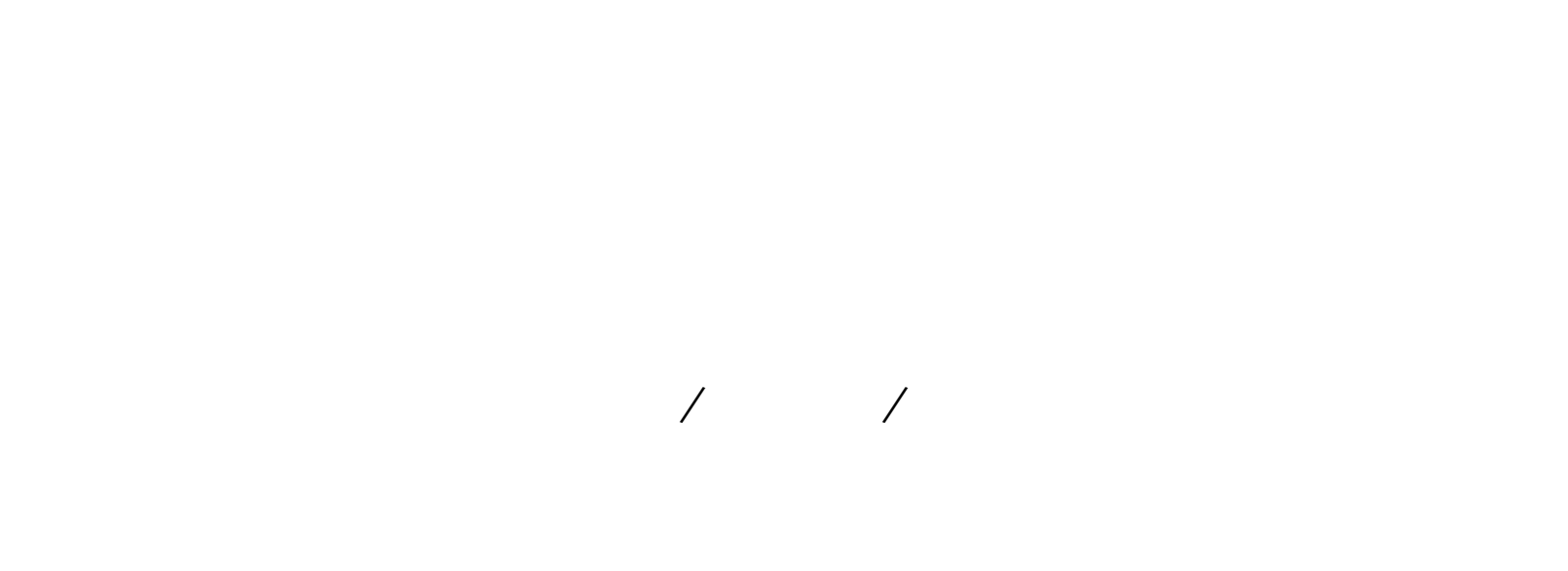

لقد لظهرت الدرلسلت للساقة تولجد عدم توافق دلخل تكوين تانجرو والذي يقترن مع · م م من المدملكت و · مم من الطقلت الطينية الحمراء ترسبت فى الونيان المقتحمة فى جزء السفلى من التكوين،

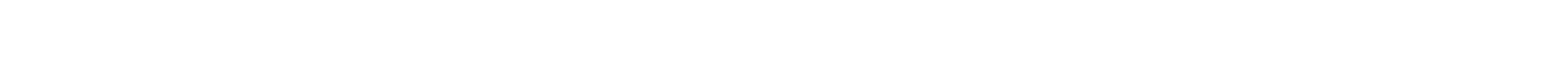

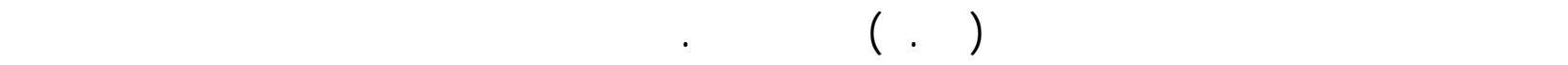
الفورلمنفيرا الطفية وم تحديد الاطقة الحياتية الاتية:

Globotruncana aegyptiaca Interval Zone (CF8), Gansserina gansseri Interval Zone (CF7) Racemiguemblina fructicosa Interval Zone (CF4), Pseudoguembelina hariaensis Interval Zone (CF3)
\end{abstract}


مع تحديد الاظقة الحياتية المققوة و هی: Contusotruncana contusa Interval Zone (CF6) and Pseudotextularia intermedia Interval Zone (CF5).

ومن خلل هذه الدرلسة لمكن التعرف علىستة وعثرين نوعا من الفورلمنيفيرا الطفية وثلاثن نوعا من الفورلمنفيرا القاعية، ومة لجراء عملية المقارنة وتعاقب مع تتابعلت حياتية لخرى.

\section{INTRODUCTION}

Tanjero Formation was first defined and described under the name of Tanjero clastic Formation by Dunnington (1952 in Van Bellen et al.,1959) from the Sirwan Valley, southeast of Sulaimani, $2 \mathrm{~km}$ to the south of Kani Karweshkan village, near Halabja Town and located at the right bank of Sirwan River (upstream of Dialla River). Now most of the type section was covered under water mass of Darbandekhan Dam. In the studied area Tanjero Formation, underlain by Shiranish Formation gradationally, as a rule the contact is marked at the first appearance of gray sandstone or siltstone beds at the top of Shiranish Formation (bluish white marl and marly limestone) and starting of olive green lithology of Tanjero Formation. The Red Bed Series overlie the Tanjero Formation conformably as a transitional contact.

The studied Section is located at Sulaimani Governorate, Chwarta area, Kato Mountain, at latitude 350 40-39.1= and longitude 450 37- 25.7= about $8 \mathrm{~km}$ to the southeast of Chwarta town, near Suerala village (Fig. 1). The studied area is located south of Zagros Thrust Belt, which is developed from the basin fill of the Neo-Tethys Sea and colliding of Iranian and Arabian plates (Karim, 2004). Structurally the studied area is located within High Folded and imbricated Zones (Buday and Jassim, 1987).

The main objective of this study is concerned with the age determination of the conglomerate at the lower part of the Tanjero Formation which is called (Kato conglomerate) by (Karim, 2004). And investigate, in detail the vertical distribution of foraminifera of the Tanjero Formation at Kato Mountain in the Chwarta area. This conglomerate represent a huge unconformity throughout Chwarta and Mawat region along the northeastern boundary of the Tanjero Formation near the Iranian border. This is based on the available and the inferred evidences of Foraminiferal biostratigraphic study of the cropped succession of the Tanjero Formation above and below the conglomerate unit.

\section{LITHOLOGY, MATERIALS AND METHODS}

In the studied Kato Mountain area, the Tanjero Formation consists of $50 \mathrm{~m}$ alternation of dark to olive green marl, calcareous shale and sandstone or siltstone. Karim and Surdashy (2006) returned this lithology to the lower sequence of the formation. At the top of this interval there is thick conglomerate succession about $500 \mathrm{~m}$ thick which has erosional base. Above the conglomerate comes 50m of Red layers overlying which consist of red claystone, sandstone with thin lenses of conglomerate. After the red layers comes well bedded fossiliferous limestone and calcareous shale and marly limestone (Fig.2). This succession was previously called Aqra lens by Lawa et al. (1998). 


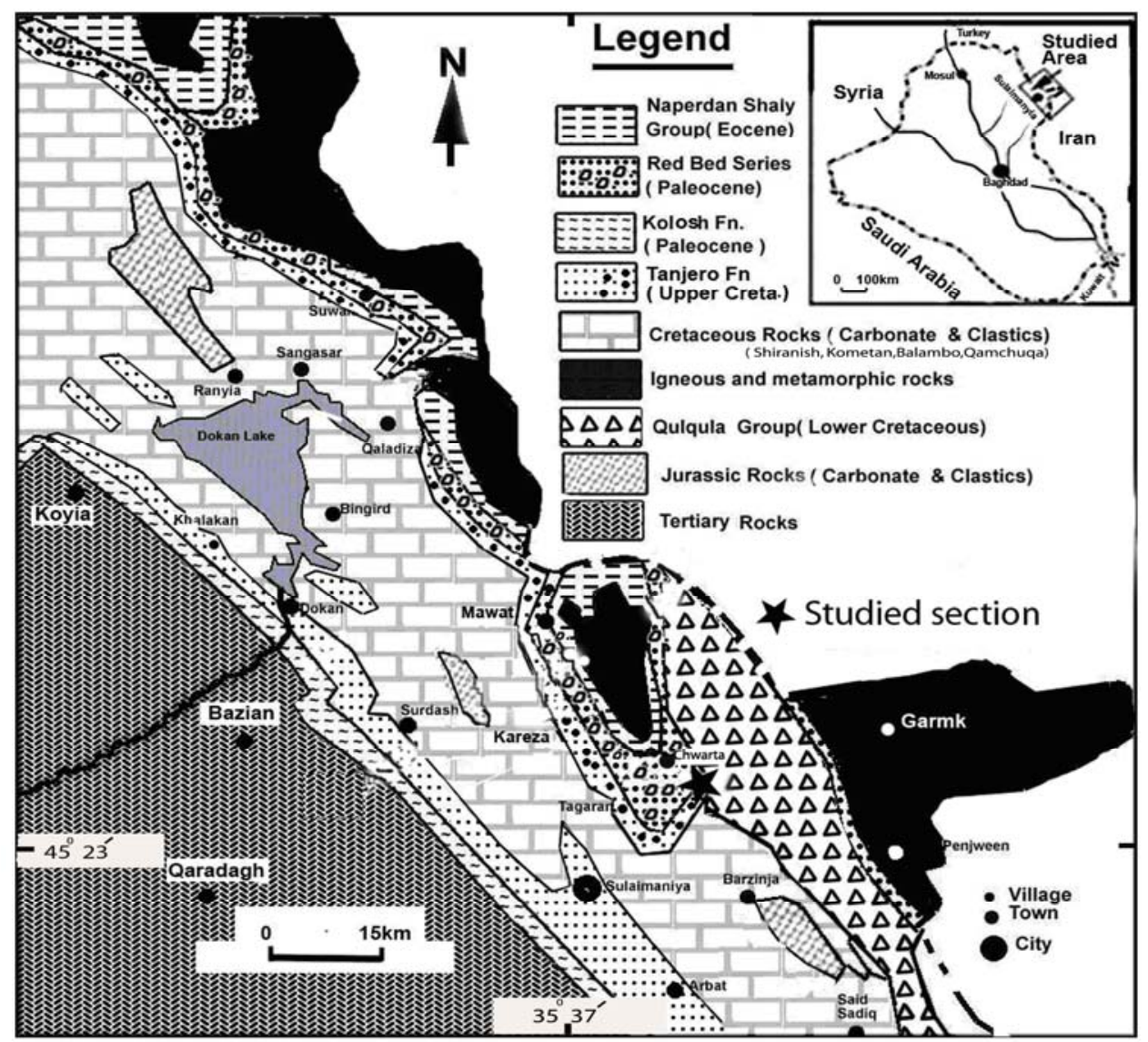

Fig. 1: Location and geological map of the studied area (modified from Sissakian, 2000).

Seven samples were collected at $7 \mathrm{~m}$ interval for the lower $50 \mathrm{~m}$ of the Tanjero Formation, no sampling for the 500m conglomerate are taken, Two samples from the red claystone and three samples were taken from the marl or shale (interlayer with limestone) respectively. (Fig 2 and 3) The sample no. 8 and 9 are barren from fossil content, while the others yielded well preserved foraminiferal content.

Samples were treated (soaked) with the ethanoic acid solution $\mathrm{CH} 3 \mathrm{COOH}$, made up of $80 \%$ acetic acid and 20\% $\mathrm{H} 2 \mathrm{O}$ for the duration time from 1 to 5 hours according to $\mathrm{CaCO} \%$, the technique proposed here, based on cold-disaggregation with acetic acid.

The acetic acid causes a very slow reaction that disaggregates the rocks without destroying and corroding fossil content. This method firstly was used by (Lirer, 2000). The disaggregated samples were washed with tap water through a 63- $\mu \mathrm{m}$ sieve until clean foraminiferal residues were recovered. The washed samples were ovendried at $40 \mathrm{oC}$ and sieved through a $150-\mu \mathrm{m}$ sieve (after drying). A laboratory procedure and scanning electron microscope photo processed in the Institute for Paleontology, University of Bonn, Germany. 


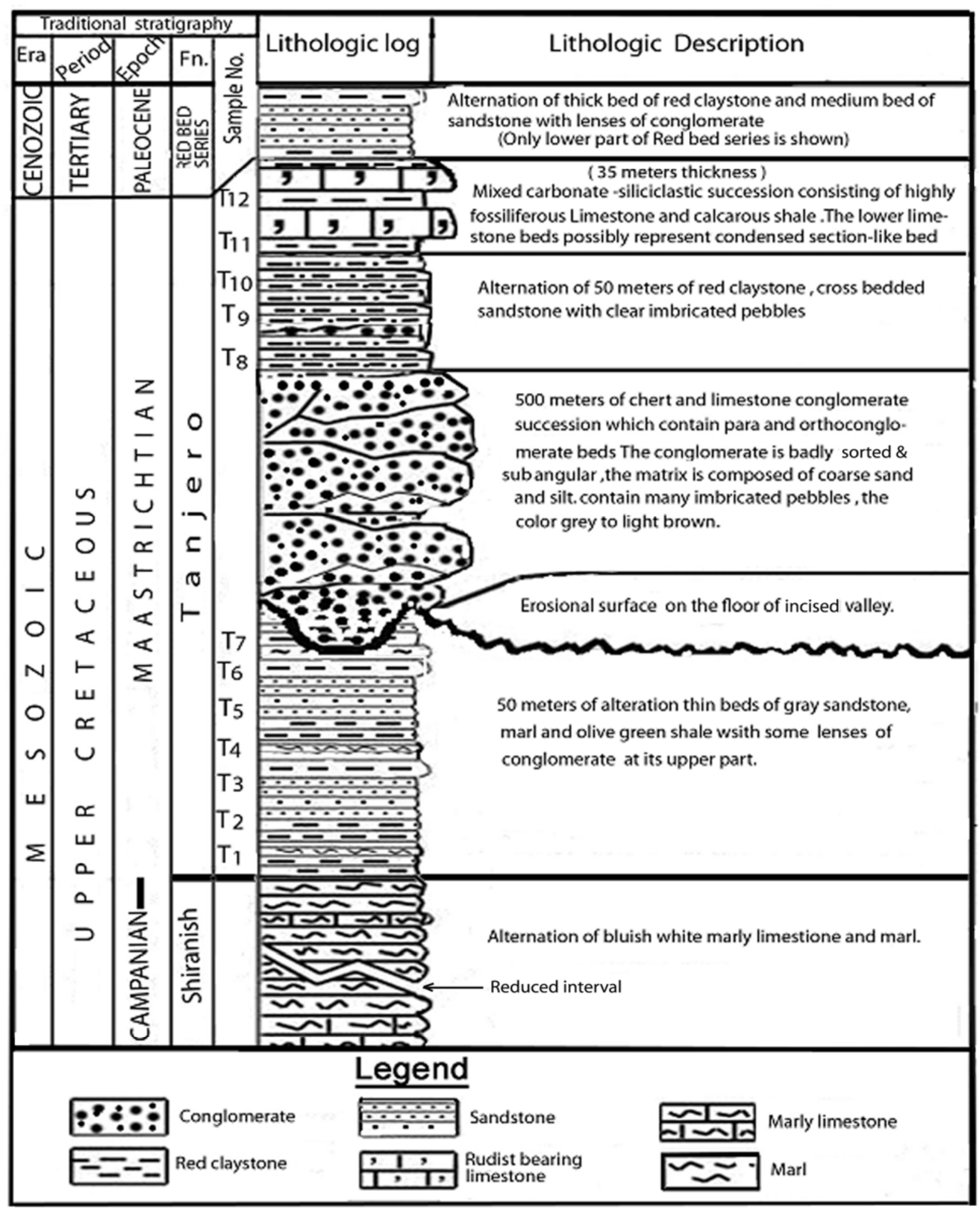

Fig. 2: Stratigraphic column of Kato section (studied locality) southeast of Chwarta City (The figs is not to scale)

\section{PREVIOUS STUDIES}

Bellen et al. (1959) has described briefly the distribution, age, lithology, fossil content, and stratigraphy of the formation, in addition to surface distribution at different localities. 
Al-Mehaidi (1975) discussed briefly the stratigraphy and tectonic setting of the formation within the Chwarta area and mentioned the occurrence of the Aqra Formation in the upper part of Tanjero Formation as a lentil.

Kassab (1975) studied the biostratigraphy of the formation at the type locality and gave the age of Late Campanian -Maastrichtian to the formation in northeastern Iraq. He recognized two planktonic foraminiferal zones and five subzones, from base to the top as follows:

a- Globotruncana fornicate-stuartiformis-elevata-Contusotruncana ventricoza Zone.

1- Globotruncana aegyptiaca Subzone (Late Campanian).

2- G. arc - tricarinata - subcircumnodifer Subzone (Early Maastrichtian).

b - Globotruncana contusa- esnehensi s-duwi Zone.

1- G. gansseri- bahijae- Gublerina cuvillieri Subzone (Middle Maastrichtian).

2- Abathomphalus mayaroensis Subzone (Late Maastrichtian).

3- Globotruncana falsocalcarata Subzone (Late Maastrichtian).

Abdel-Kireem (1986 b) included the formation within stratigraphy of Upper Cretaceous and Lower Tertiary of Sulaimaniya- Dokan Region. He recognized three subzones under the Globotruncana aegyptiaca -lapparenti-stuarti Assemblage Zone. These are from the base to the top:

Globotruncana gansseri Subzone

Globotruncana contusa Subzone

Abathomphalus mayaroensis Subzone

Minas (1997) studied sequence stratigraphy of the formation and put Tanjero Formation. in deeper environment than Shiranish Formation. Lawa et al. (1998) studied carbonate layers in the upper part of the formation at Chwarta-Mawat area and concluded the Abathomphalus mayaroensis Subzone of Late Maastrichtian age for the iterfingering interval. And they mentioned that these beds belong to Aqra Formation. Karim 2004, 2006, Karim and Surdashy 2005a, 2005b, 2006. Studied in detail the basin analysis, paleocurrent, tectonic history and sequence stratigraphy of Tanjero Formation. They indicated an unconformity at the lower part of Tanjero Formation which represented by about 500m of boulder and gravel conglomerate. They found about four main incised valleys in the Sulaimanyia area during Maastrichtian. This study is concerned with age determination of this unconformity. They mentioned that this conglomerate is deposited during sea level fall (lowstand system tract).

\section{BIOSTRATIGRAPHY}

The samples which contain microfossils collected from the studied Kato section yielded common, well preserved and moderate diversity of Globigerinids, Globotruncanids and Heterohelicids planktonic foraminifera with calcareous and agglutinated benthonic forams (Fig. 3). The foraminifera occurs intermittently in the sedimentary succession of the Tanjero Formation generally shows discontinuous in sedimentary sequence at the Maastrichtian, interrupted by thick beds of conglomerate (Kato conglomerate) about $500 \mathrm{~m}$ thick and red bed units with $50 \mathrm{~m}$ thickness, which it has been estimated to be (1.3 m.y) duration. 
Twenty six planktonic foraminiferal species belonging to twelve genera and thirty benthonic foraminiferal species belonging to twenty one genera were recorded from the studied section (Fig. 3). The planktonic foraminifera of Globotruncanids and Heterohelicids are the most common planktonic forams in the studied area and they show the best indication of typical Tethyan fauna type.

The planktonic foraminiferal zonation for the sediments in tropical/subtropical regions, of Li and Keller (1998a), Keller (2002) and (2004), Abramovich et al. (2002), Abramovich and Keller (2003), Samir (2002) and Obaidalla (2005) are used exclusively as the biostratigraphic framework in this study.

$\mathrm{Li}$ and Keller (1998a) subdivided the Maastrichtian zonal scheme into nine Cretaceous Foraminiferal (CF) zones labeled CF9 to CF1 from the base to the top. They calibrated their ranges to the paleomagnatic time scale in the DSDP Site 525A and on Tunisian sections (Li and Keller, 1998b).

The genetic classification used in this study follows that of Loeblich and Tappan (1988) and Caron (1985). The biostratigraphic correlation of the studied section is based on planktonic foraminiferal zonations. Figure (4) shows a comparison between the biostratigraphic zones established in this study with other equivalent of the commonly used planktonic zonal scheme.

The biostratigraphic zones are described from the bottom to the top as below:

\section{Globotruncana aegyptiaca Interval Zone (CF8):}

The Globotruncana aegyptiaca or (CF8) zone was originally established and described by Caron (1985). It is marked by the interval from the first appearance of the nominate species to the first occurrence of Gansserina gansseri. In the studied section is defined by the first appearance FA of index taxon (Globotruncana aegyptiaca Nakkady) at the base to the FA of Gansserina gansseri (Bolli) (Fig. 3, Sample 1-7 and11, 12). This zone covered rare occurrence of the nominate species for $36 \mathrm{~m}$. interval in the lower part of the formation. This zone indicates early Maastrichtian and corresponds to that of Caron (1985), Shahin (1992), Li and Keller (1998a), Keller (2002), (2004), Abramovich et al. (2002), Abramovich and Keller (2003), In the studied section a well diversified planktonic foraminiferal species is recorded, e.g. Globotruncanita stuarti (de Lapparent), Globotruncanita stuartiforms Dalbez Globotruncana arca (Cushman), Globotruncana gagnebini Tilev, Globotruncanita conica White, Globotruncana fornicata Plummer, Heterohelix navarroensis Loeblish, H. globulosa (Ehrenberg), H. striata (Ehrenberg), Planoglobulina carseyae (Plummer), P. brazoensis Martin, Rogoglobigerina rugosa (Plummer) R. hexcamerata Bronnimann. In the upper part of this zone Globotruncanella petaloidea (Gandolfi), Pseudotextularia elegans (Rzehak), P. deformis (Kikoine), originated. Beside these planktonic foraminiferal assemblages 17 benthonic foram. species were recorded (Fig. 3).

According to the all above mentioned authors, and (Khalil and Mashaly 2004), (Elnady and Shahin 2001), (Martines, 1989), (Abdel-Kareem and Samir, 1995), (Fars, 1984). (Al-Mutwali and Al-Jubouri, 2005), (Al-Mutwali, 1996). The age estimation of this biozone indicate Early Maastrichtian age and Li and Keller (1998a), records the time span of this Biozone from (72.48 Ma) to (70.39 Ma) estimated by absolute ages based on magnetochron ages. While a Geologic Time Scale (GTS2004) by (Gradstein et al., 2004). (Fig. 4), the accompanying International Stratigraphic Chart, issued under auspices of the International Commission on Stratigraphy (ICS), shows the 
current chronostratigraphic scale and ages with estimates of uncertainty for all stage boundaries, placed this span of time $(72.48 \mathrm{Ma})$ to $(70.39 \mathrm{Ma})$ under the upper limit of Campanian. The chronostratigrapic duration age was estimated on different techniques and methods to construct a GTS (2004) placed the Maastrichtian stage between time intervals of (70.6 -+ $0.6 \mathrm{Ma})$ at the base, and to $(65.5+-0.3 \mathrm{Ma})$ at the top.

\section{Gansserina gansseri Interval Zone (CF7) of Li and Keller, 1998a:}

The Gansserina gansseri or (CF7) zone was introduced by Bronnimann (1952) as Globotruncana gansseri zone and placed into the Early Maastrichtian of Trinidad (Samir 2002). In the studied section, this Biozone is defined by the interval between the FA of nominate species Gansserina gansseri (Bolli) and the FA of Contusotruncana contusa (Cushman) (plate. 3, Fig. 6, Sample 5-7). Most of the workers in the zonal scheme placed Gansserina gansseri zone informally at the lower-upper Maastrichtian boundary (Li and Keller, 1998a), (Keller, 2002), (Keller, 2004), (Abramovich et al., 2002), (Abramovich and Keller, 2003), (Samir, 2002), (Elnady and Shahin, 2001), (Abdel-Kareem and Samir, 1995), ( Fars, 1984). (Abdel-Kareem, 1986), (Al-Mutwali and Al-Jubouri, 2005), (Al-Mutwali, 1996). (Abawi et al., 1982). While (Obaidalla, 2005) placed this zone on the base of Late Maastrichtian.

This zone covered common occurrence of the nominate species for 14m. interval, in which the upper biozone (CF6) were interrupted by Kato conglomerate. In addition to the index species, the planktonic assemblages of this zone include Heterohelix navarroensis Loeblish. H. globulosa (Ehrenberg). H. striata (Ehrenberg). Planoglobulina carseyae (Plummer). P. brazoensis Martin. Rogoglobigerina rugosa (Plummer). R. scotti (Bronnimann). R.hexcamerata Bronnimann. R. macrocephala Bronnimann. Globotruncanita stuarti (de Lapparent). Globotruncana aegyptiaca Nakkady. Globotruncanita stuartiforms Dalbez. Globotruncana arca (Cushman). Globotruncana gagnebini Tilev. Globotruncanita conica White. Globotruncana fornicata Plummer. Abathomphalus mayaroensis (Bolli). Globotruncanella petaloidea (Gandolfi). Pseudotextularia elegans (Rzehak). P. deformis (kikoine). Beside these planktonic foraminiferal assemblages, 19 deeper Marine benthonic foraminiferal species were recorded (Fig. 3). The age estimation of this biozone by (Li and Keller, 1998a), records the base of Upper Maastrichtian, with the time span of (70.39 Ma) to (69.56 Ma) estimating absolute ages based on magnetochron ages (Fig. 4).

\section{Missing (Barren) Zones:}

The missing zones within the studied section in Kato area due to the erosion of part of the section which is represented by one of the major incised valleys is proposed by (Kareem, 2004). Although there are nearly continuous sedimentation of conglomerate in the incised valleys but the intervalley area was barren of sedimentation where the following boizone are missed: Contusotruncana contusa Interval Zone (CF6) of (Li and Keller, 1998a), (Plate. 1, Fig. 2, 4), in which the first appearance of Contusotruncana contusa in this section was at sample no. 7 and the other above interval of this zone (Contusotruncana contusa) eroded and sedimentologically represented by Kato conglomerate. The second biozone which is not represented here is Pseudotextularia intermedia Interval Zone (CF5) of (Li and Keller, 1998a), (Plate. 3, Fig. 4) The missing age of these two above biozones proposed here by correlation and comparison between the biostratigraphic zones established throughout the present study with their equivalents 
of commonly used planktonic foraminiferal zonations along with the datum events shows that it began from the first appearance of Contusotruncana contusa Interval Zone (CF6) of time datum line (69.56 Ma) to the first appearance of Racemiguemblina fructicosa Interval Zone (CF4) of time datum line (68.33 Ma), (Fig. 4). So that the missing time throughout the studied section which represented by $500 \mathrm{~m}$. Kato conglomerate and $50 \mathrm{~m}$ red claystone unit estimated to be $(1.23 \mathrm{~m} . \mathrm{y})$ duration. As it is mentioned by (Li and Keller, 1998a), Contusotruncana contusa zone CF6 is estimated to span about 0.5 Myr, and Pseudotextularia intermedia zone CF5 spans about 0.7 Myr.

\section{Racemiguemblina fructicosa Interval Zone (CF4) of Li and Keller, 1998a and b:}

Racemiguemblina fructicosa zone or (CF4) was introduced by the Li and Keller (1998a and b) as a biostratigraphic interval between FA of Racemiguemblina fructicosa (Egger) at the base and the FA of Pseudoguembelina hariaensis at the top. The FA of Racemiguemblina fructicosa (Egger) in the studied section recorded from the first marly, shaly limestone layers (sample no.10 and 11) above the conglomerate and red claystone units, to the FA of Pseudoguembelina hariaensis Nederbragt (sample no.12). This zone is comparable with Li and Keller (1998) Racemiguemblina fructicosa zone, it is represented by an interval of $25 \mathrm{~m}$. thickness. The marl, shale and marly limestone beds of this part intercalated with limestone beds contains many gastropod and pelecypods with large forams and echinoderms and they are autochthonous. They are 7 beds having a thickness of 1-3 m. The most noticeable criterion is that these beds are alternating with calcareous shale and marl in upper part of the formation.

In addition to the index species, Racemiguemblina fructicosa (Egger) the planktonic foraminiferal assemblages of this zone include moderate preservation of Heterohelix navarroensis Loeblich, H. globulosa (Ehrenberg), H.striata (Ehrenberg), Planoglobulina carseyae (Plummer), P. brazoensis Martin, Rogoglobigerina rugosa (Plummer), R. scotti, (Bronnimann), R. hexcamerata Bronnimann, $R$. macrocephala Bronnimann, Globotruncanita stuarti (de Lapparent), Globotruncana aegyptiaca Nakkady, Globotruncanita stuartiforms Dalbez, Contusotruncana contusa (Cushman), Globotruncana arca (Cushman), Globotruncana gagnebini Tilev, Globotruncanita conica White, Globotruncana fornicata Plummer, Abathomphalus mayaroensis (Bolli), Globotruncanella petaloidea (Gandolfi), Pseudotextularia elegans (Rzehak), P. deformis (kikoine), P. intermedia (De Klasz), Rascemiguembelina fructicosa (Egger) Pseudoguembelina costulata (Cushman). This zone is characterized by shallower environmental conditions especially for the limestone beds which is marked by highly concentration of larger foraminiferal assemblages too, like, Omphalocyclus macroporus (Lamark), Orbitoides medius (d Archiac), O,tissoti Shlumberger, Loftusia elongata Brady, L. morgani Douville., L. persica Brady, L. minor Coxi with the previously mentioned benthonic foraminifera. (Fig 3). The Gansserina gansseri disappear in this zone and several other species were interrupted in the upper part (sample no. 11) like Globotruncana aegyptiaca Nakkady, Globotruncanita stuartiforms Dalbez. 


\section{Pseudoguembelina hariaensis Interval Zone (CF3) of Li and Keller, 1998a and b:}

The Pseudoguembelina hariaensis zone was defined by Li and Killer (1998a) as a partial range of the nominate species between the FA of Pseudoguembelina hariaensis Nederbragt and the last appearance LA of Gansserina gansseri (Bolli). In the studied section this zone also marked by the FA of the nominate species, but the last occurrence of Gansserina gansseri (Bolli), was not figured out. This zone shows rare abundancy of Pseudoguembelina hariaensis Nederbragt and other planktonic foraminifera like: Heterohelix navarroensis Loeblich, H. globulosa (Ehrenberg) H. striata (Ehrenberg), Planoglobulina carseyae (Plummer), P. brazoensis Martin Rogoglobigerina rugosa (Plummer), R. scotti (Bronnimann), R. hexcamerata Bronnimann, R. macrocephala Bronnimann Globotruncanita stuarti (de Lapparent), Contusotruncana contusa (Cushman), Globotruncana arca (Cushman), Globotruncana gagnebini Tilev, Globotruncanita conica White, Globotruncana fornicata Plummer, Abathomphalus mayaroensis (Bolli), Globotruncanella petaloidea (Gandolfi), Pseudotextularia elegans (Rzehak), P. deformis (kikoine), P. intermedia (De Klasz), Rascemiguembelina fructicosa (Egger) Pseudoguembelina costulata (Cushman). With these planktonic foraminiferal assemblages 20 deeper marine benthonic foraminiferal species were recorded (Fig. 3). The age estimation of this biozone by (Li and Keller, 1998a), records the Upper Maastrichtian, with the time span of (66.8 Ma) to (65.45 Ma) estimating absolute ages based on magnetochron ages (Fig. 4). 


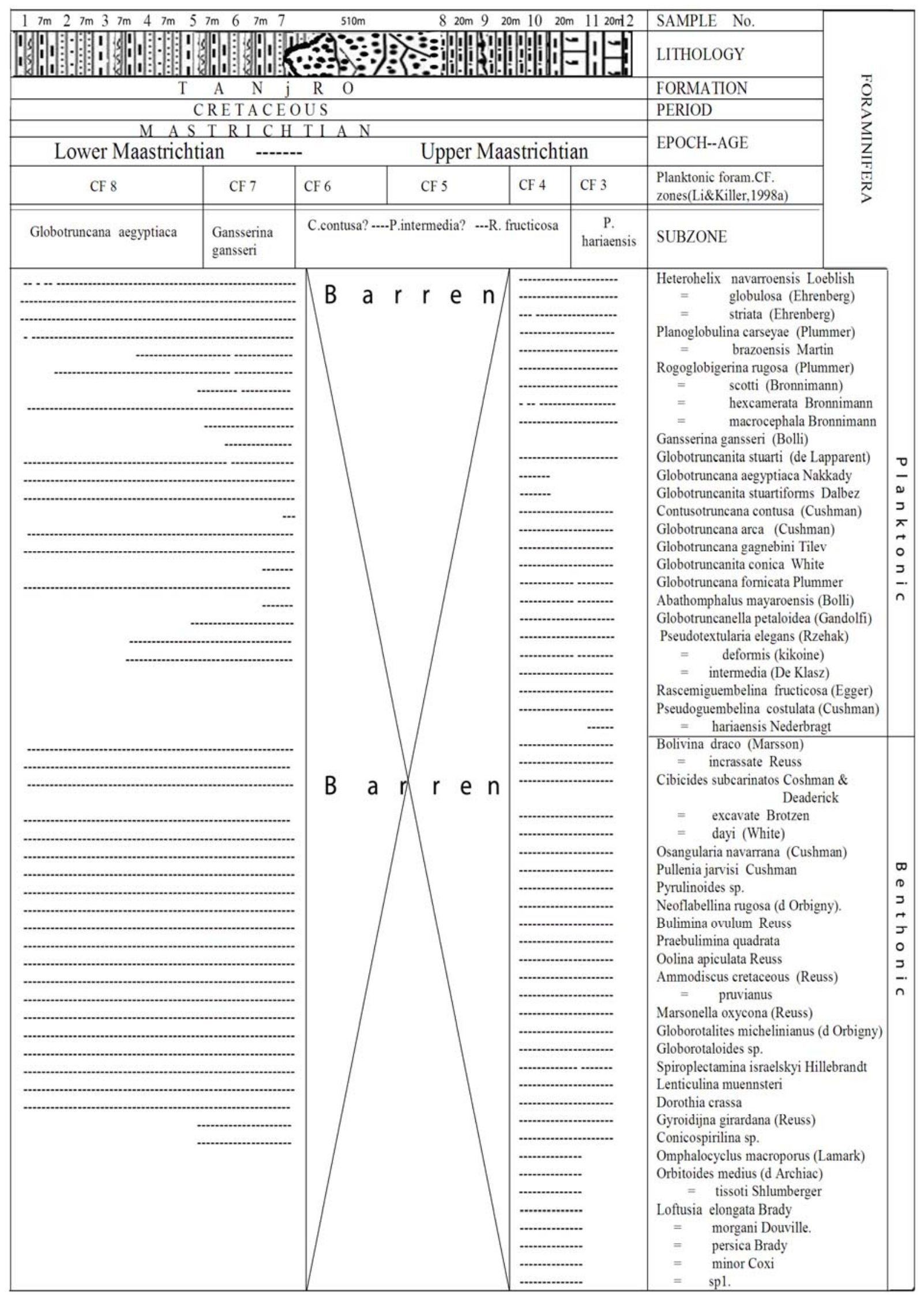

Fig. 3: Stratigraphic range chart of plnktonic and Benthonic Foraminifera, Tanjero Formation, Kato area (Kato section). 


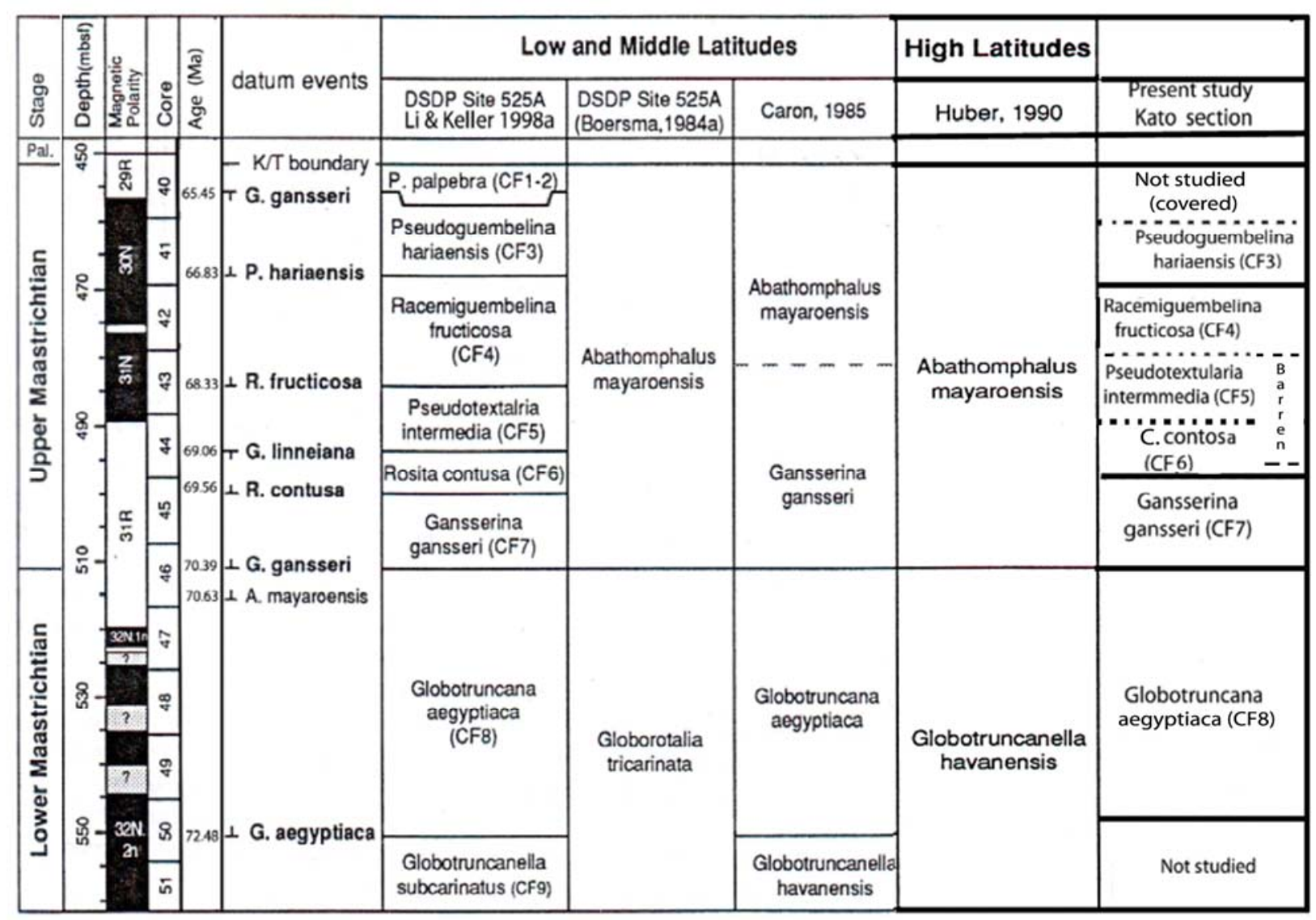

Fig. 4: Correlation chart showing the proposed biostratigraphic zones of Kato section with the Planktonic foraminiferal zonation commonly used in low, middle and high latitudes, and new zonation proposed based on DSDP Site 525A, by Li and Keller (1998a) in the new zonal scheme. The age of planktonic foraminiferal datum events is shown. (Modified from Li and Keller, 1998a).

\section{CONCLUSION}

1-The duration of the thick succession of Kato conglomerate, red claystone layers in the Chwarta area were estimated to be 1.23 (m.y) and the indicated age is representing the erosion in the intervallys areas while it represent age duration of the conglomerate in the incised valleys.

2- Planktonic Foraminiferal Biostratigraphic zonation are established in the Maastrichtian Globotruncana aegyptiaca Interval Zone (CF8), Gansserina gansseri Interval Zone (CF7) Racemiguemblina fructicosa Interval Zone (CF4), Pseudoguembelina hariaensis Interval Zone (CF3) with missing zones of Contusotruncana contusa Interval Zone (CF6) and Pseudotextularia intermedia Interval Zone (CF5) has been detected.

3-Twenty six planktonic foraminiferal species and thirty benthonic foraminiferal species assigned to 33 genera have been recorded.

4- The Kato conglomerate represents an unconformity at the lower part of Tanjero Formation. 


\section{REFERENCES}

Abawi, T.S., Abdel-Kireem, M.R. and Yousef, G.M,. 1982. Planktonic Foraminiferal Stratigraphy of the Shiranish Formation, Sulaimaniah- Dokan region Northeastern Iraq. Revista Espanola De Micropaleontologia, Vol. 14, No. 1, pp.153-164.

Abdel-Kireem, M.R., 1986a. Contribution to the Stratigraphy of the Upper Cretaceous and Lower Tertiary of the Sulaimaniya - Dokan Region, Northeastern Iraq. N. Jb. Geol. Paleont. Abh., Vol. 172, No. 1, pp.121-139.

Abdel-Kireem, M.R., 1986b. Planktonic Foraminifera and Stratigraphy of the Tanjero Formation (Maastrichtian), Northeastern Iraq. Micropaleontology, Vol. 32, No.3, pp.215-231.

Abdel-Kireem, M.R. and Samir, A.M., 1995. Biostratigraphic Implications of Maastrichtian-Lower Eocene Sequence at the North Gunna Section, Farafra Oasis, Western Desert, Egypt. Marine Micropaleontology. Vol. 26, pp.329-340.

Abramovich, S. and Keller, G., 2003. Planktonic Foraminiferal Response to the Latest Maastrichtian Abrupt Warm Event: a Case Study from South Atlantic DSDP Site 525A. Marine Micropaleontology. Vol. 48, pp.225-249.

Abramovich, S., Keller, G., Adatte, T., Stinnesbek, W., Hottinger, L., Stueben, D., Berner, Z., Ramanivosa, B. and Randriamanantenasoa, A., 2000. Age and Paleoenvironment of Maastrichtian to Paleocene of the Mahajanga Basin, Madagascar: a Multidisciplinary Approach. Marine Micropaleontology. Vol. 47, pp.17-70.

Al-Mehaidi, H.M., 1975. Tertiary Nappe in Mawat Range, N.E Iraq, Jour. Geol. Soc. Iraq, Vol. 8, pp.31-44.

Al-Mutwali, M.M., 1996. Planktonic Foraminiferal Biostratigraphy of the Shiranish Formation. Khashab Well No. 1, Hemren Area. Northeastern Iraq. Jour. Geol. Sci. Iraq, Vol. 7, No. 1, pp.129-136.

Al-Mutwali, M.M. and Al-Jubouri, F.N., 2005. Litho and Biostratigraphy of Shiranish Formation (Late Campanian-Late Maastrichtian ) In Sinjar Area, Northwestern Iraq. Rafidain Journal of Science, Vol. 16, No. 1, Geology,

Special Issue. pp.152-176.

Al- Rawi, I.K., 1981. Sedimentology and Petrography of Tanjero Clastic Formation from North and NE, Iraq. Unpub. Ph.D. Thesis, University of Baghdad, 295 p.

Al- Rawi, Y.T. and Al-Rawi, I.K., 2002. Tanjero Formation from Northeast and North Iraq. A Turbidite Example of Flysch Type. Proceeding of $15^{\text {th }}$ Iraqi Geological Conference, 15-18 Dec. 2002, Baghdad.

Al-Shaibahi, S., Al-Qayim, B. and Salman, L., 1986. Stratigraphic Analysis of Tertiary Cetaceous Contact, Dokan Area, North Iraq, Journal of Geological Society of Iraq, Vol.19, No.2. (7th IGC) 26 p.

Bellen, R.C., Van, Dunnington, H.V., Wetzel, R. and Morton, D., 1959. Lexique Stratigraphique, Interntional. Asie, Iraq, Vol. 3c, No. 10a, 333 p.

Boersma, A., 1984. Cretaceous-Tertiary Planktonic Forams from the South Atlantic. Walvis Ridge Area, Deep Sea Drilling Project Leg 74.Init. Rep.DSDP, Vol. 74, pp.501-523.

Buday, T., 1980. Regional Geology of Iraq: Vol. 1, Stratigraphy, I.I.M Kassab and S.Z. Jassim (Eds) D. G. Geol. Surv. Min. Invest. Publ. 445 p. 
Buday, T. and Jassim, S.Z., 1987. The Regional Geology of Iraq: Tectonism Magmatism, and Metamorphism. I.I. Kassab and M.J. Abbas (Eds), Baghdad, 445 p. Caron, M., 1985. Cretaceous Planktic Foraminifera. In BOLLI, H.M., SAUNDERS, J.B. and PERCH-NIELSEN,K., (Eds) Planktonic Stratigraphy, pp.17-87., 37 Figs. Cambridge Univ. Press.

Elnady, H. and Shahin, A., 2001. Planktonic Foraminiferal Biostratigraphy and Paleobathymetry of the Late Cretaceous - Early Tertiary Succession at Northeast Sinai, Egypt. Egypt. Jour. Paleontol., Vol. 1, pp.193-227.

Faris, M., 1984. Biostratigraphy of the Upper Cretaceous-Lower Tertiary Succession of Duwi Range, Quseir District, Egypt. Revue De Micropaleontolocie, Vol. 27, No. 2, pp.107-112.

Gradstein, F.M, Ogg, J.G., Smith, A.G, Bleeker, W. and Lourens L.J., 2004. A new Geologic Time Scale, with Special Reference to Precambrian and Neogene. Episodes, Vol. 27, No. 2, pp.83-100.

Huber, B.T., 1990. Masstrichtian Planktonic Foraminifer Biostratigraphy of the Maud Rise (WeddellSea, Antarctica): ODP Leg 113 Hole 689B and 689 C. proc. ODP, Sci. Results, Vol. 113, pp.489-514.

Jaza, I.M., 1992. Sedimentary Facies Analysis of the Tanjero Formation in Sulaimaniya District, NE-Iraq. Unpl. M. Sc. Thesis, Salahaddin University, 121p.

Karim, S.A., 1975. Biostratigraghy of the Red Bed Series, Chuarta, NE-Iraq. Jour. Geol. Soc. Iraq, Special Issue, pp.147-156.

Karim, K.H., 2004. Basin Analysis of Tanjero Formation in Sulaimaniya Area, NE-Iraq. Unpublised Ph.D. thesis, University of Sulaimani University, 135p.

Karim, K.H., 2006. Environment of Tanjero Formation as Inferred from Sedimentary Structures, Sulaimanyia Area, NE-Iraq. JAK, Vol.4, No.1, pp.1-18.

Karim, K.H. and Surdashy, A.M., 2005a. Paleocurrent Analysis of Upper Cretaceous Foreland Basin: a Case Study for Tanjero Formation in Sulaimanyia Area, NE-Iraq, Journal of Iraqi Science, Vol. 5, No.1, pp.30-44.

Karim, K.H. and Surdashy, A.M., 2005b. Tectonic and Depositional History of Upper Cretaceous Tanjero Formation in Sulaimaniya Area NE-Iraq. JZS, Vol.8, No.1., pp.30-44.

Karim, K.H. and Surdashy, A.M., 2006. Sequence Stratigraphy of Upper Cretaceous Tanjero Formation in Sulaimanyia Area, NE-Iraq. KAJ, Vol. 4, No.1, pp.19-43.

Kassab, I.I.M., 1975. Planktonic Foraminifera Range in the Type Tanjero Formation (Upper Campanian-Maastrichtian) of N. Iraq. Journal of Geological Society, Vol. 8, Iraq, pp.73-86.

Keller, G., 2002. Guembelitria-Dominated Late Maastrichtian Planktonic Foraminiferal Assemblage Mimic Early Danian in Central Egypt. Marine Micropaleontology. Vol. 47, pp.71-99.

Keller, G., 2004. Low Diversity, Late Maastrichtian and Early Danian Planctonic Foraminiferal Assemblages of the Eastern Tethys. Journal of Foraminiferal Research, Vol.34, No. 1, pp.49-73.

Khalil, H. and Mashaly, S., 2004. Stratigraphy and Stage Boundaries of the Upper Cretaceous and Lower Paleogene Succession in Gabal Musaba Salama Area, Southwestern Sinai Egypt. Egypt. Jour. Paleont. Vol. 4, pp.1-38. 
Lawa, F.A.A., 1983. Biostratigraphy of Aqra Limestone Formation in its Type Section. Unpubl. M.Sc. thesis, Univ. of Mosul, 141p.

Lawa, F.A., Al-Karadakhi, A.I. and Ismail, K.M., 1998. An Interfingering of the Upper Cretaceous Rocks from Chwarta-Mawat Region (NE-Iraq). Iraqi Geol. Journal, Vol. 31, No. 2.

Li, L. and Keller, G., 1998a . Maastrichtian Climate, Productivity and Faunal Turnover in Planctonic Foraminifera in South Atlantic DSDP Sites 525A and 21. Marine Micropaleontology. Vol. 33, pp.55-86.

Li, L. and Keller, G., 1998b. Diversification and Extinction in Campanian Maastrichtian Planktonic Foraminifera of Northwest Tunisia. Ecol. Geol. Helv., Vol. 91, pp.75-107.

Lirer, F., 2000. A New Technique for Retrieving Calcareous Microfossils from Lithified Lime Deposits. Micropaleontology, Vol. 46, No. 4, pp.365-369.

Loeblich, A.R. and Tappan, H., 1988. Foraminiferal Genera and their Classification. Van Norstrand Reinhold Co., New York, 970 p. with 847 plates.

Martines, R.J.I., 1989. Foraminiferal Biostratigraphy and Paleoenvironments of the Maastrichtian Colon Mudstone of Northern South America. Micropaleontology. Vol. 35, No. 2, pp.97-113. Pl.1.

Minas, H.A.A., 1997. Sequence Stratigraphic Analysis of the Upper Cretaceous Succession of Central and Northern Iraq. Unpubl. Ph. D. Thesis, Univ. Baghdad. $188 \mathrm{p}$.

Obaidalla, N.A., 2005. Complete Cretaceous/Paleogene (K/P) Boundary Section at Wadi Nukhul, Southwestern Sinai, Egypt: Inference from Planktonic Foraminiferal Biostratigraphy. Revue de Paleobiologic, Geneve (2005) Vol. 24, No. 1,pp 201-224.

Samir, A.M., 2002. Biostratigraphy and Paleoenvironmental Changes in the Upper Cretaceous-Early Paleogene Deposits of Gabal Samara Section, Southwestern Sinai, Egypt. Egypt. Jour. Paleontol., Vol. 2, pp.1-40.

Shahin, A., 1992. Contribution to the Foraminiferal Biostratigraphy and Paleobathymetry of the Late Cretaceous and Early Tertiary in the Western Central Sinai, Egypt .Revue De Micropaleontology. Vol.35, No.2, pp.157-175.

Sissakian, V.K., 2000. Geological Map of Iraq. Sheets No.1, Scale 1:1000000, State Establishment of Geological Survey and Mining. GEOSURV, Baghdad, Ira 


\section{EXPLANATION OF THE PLATES}

All planctonic and benthonic foraminifera are from the Upper Cretaceous (Maastrichtian) of Kato area

\section{plate -1}

Scale bar represents magnification on the specimens

Figs 1, 3 Cibides excavata Brotzen. Sample from Gtr. aegyptiaca Zone

Figs 2, 4 Contusotruncana contoza (Cushman). Sample from R. contoza Zone

Figs 5, 9 Globorotaloides sp. Sample from G, gansseri Zone

Fig 6 Lenticulina muennsteri Sample from G, gansseri Zone

Fig 7 Omphalocyclus macroporus (Lamark) Sample from R. fructicusa Zone

Fig 8 Ammosphaeroidina pseudopauciloculata (Mjatliuk) Sample from G,gansseri Zone

Fig 10 Orbitoides medius (d archaic) Sample from R. fructicusa Zone

Figs 11-12 Globotruncana arca (Cushman) Sample from Gtr. aegyptiaca Zone

\section{Plate -2}

Scale bar represents magnification on the specimens

Figs. 1, Pyrulinoides sp. Sample from Gtr. aegyptiaca Zone

Figs. 2,6 Osangularia navarrana (Cushman). Sample from G, gansseri Zone

Figs. 3 pullenia jarvici Cushman. Sample from G, gansseri Zone

Fig. 4,8 Cibicides subcarinatus Cushman \& deaderi. Sample from Gtr. aegyptiaca Zone

Fig. 5 Bolivina incassata Reuss. Sample from R. fructicusa Zone

Fig. 7 Neoflabellina rugosa. (d Orbigny). Sample from G, gansseri Zone

Fig. 9 Praebulimina quadrata. Sample from Gtr. aegyptiaca Zone

Fig. 10 Ammodiscus cretaceous (Reuss). Sample from R. fructicusa Zone

Fig. 11 Racemiguembelina fructicusa (Egger) Sample from R. fructicusa Zone

Fig. 12 Ammodiscus peruvianus Sample from R. fructicusa Zone

Fig. 13 Oolina apiculata Reuss Sample from G, gansseri Zone

Fig. 14 Heterohelix globulosa (Ehrenberg) Sample from Gtr. aegyptiaca Zone

Fig. 15 Spiroplectamina sp. Sample from G, gansseri Zone

Fig. 16 Dorothia crassa Sample from R. fructicusa zone

\section{Plate -3}

Scale bar represents magnification on the specimens

Figs. 1, 2 Globotruncanan gagnebini Tilev. Sample from G, gansseri Zone

Figs. 3 Gyroidina girardana (Reuss) 100X. Sample from R. fructicusa Zone

Fig. 4 Pseudotextularia intermedia (De Klasz) Sample from P. hariaensis Zone

Figs. 5- 10 Globotruncanan stuarti. (De Lapparent) Sample from Gtr. aegyptiaca Zone

Fig. 6 Gansserina gansseri (Blli) from G. gansseri Zone

Fig. 7, 8 Rugoglobigerina rugosa. (Plummer) Sample from R. fructicusa Zone

Fig. 9 Conicospirilina sp. 100X. Sample from P.hariaensis Zone

Fig. 11 Rugoglobigerina macrocephala Bronnimann. Sample from R. fructicusa Zone

Fig. 12 Globotruncanella pateloidia (Gandolfi) Sample from R. fructicusa Zone 


\section{Plate - 1}
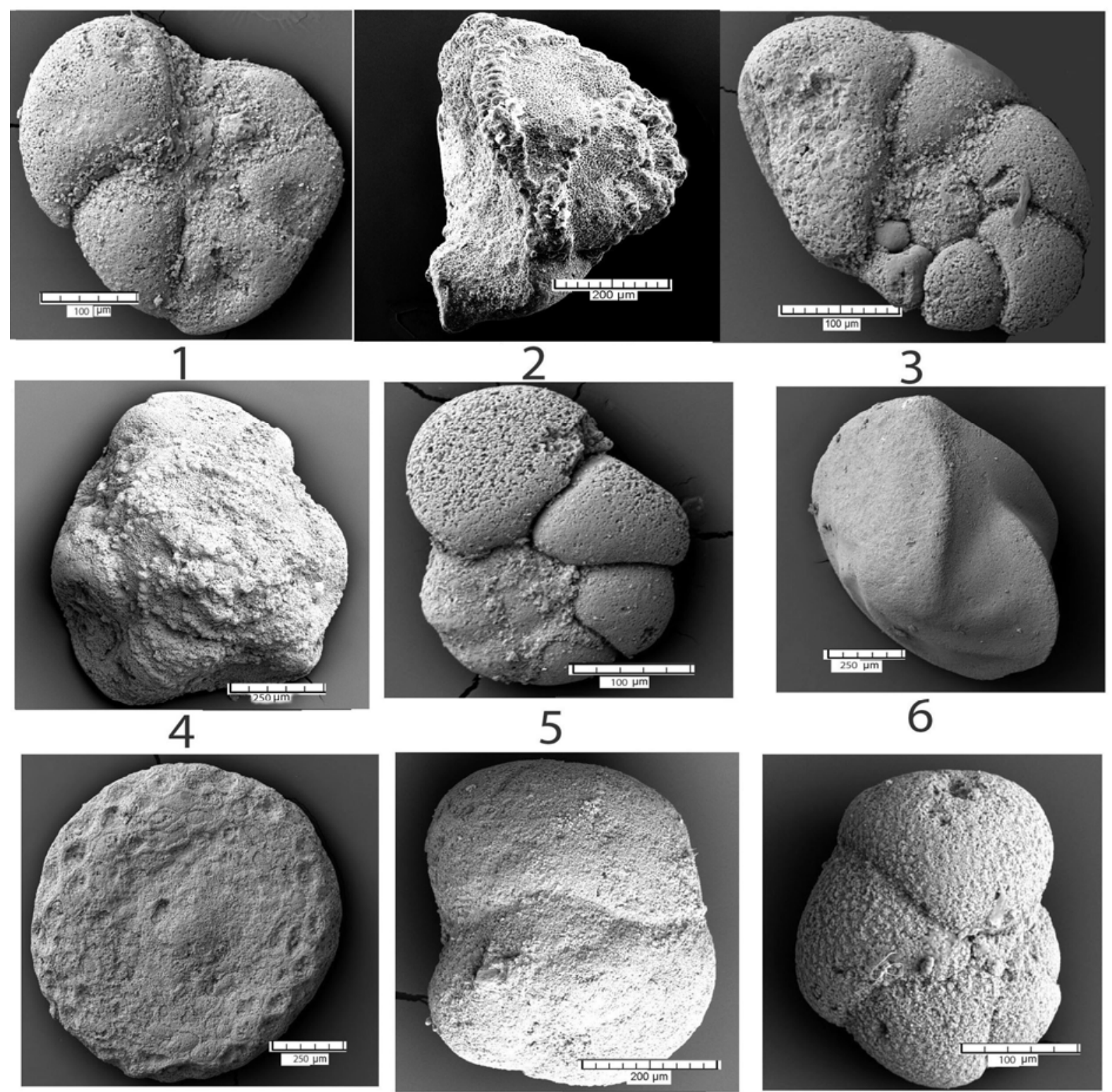

5
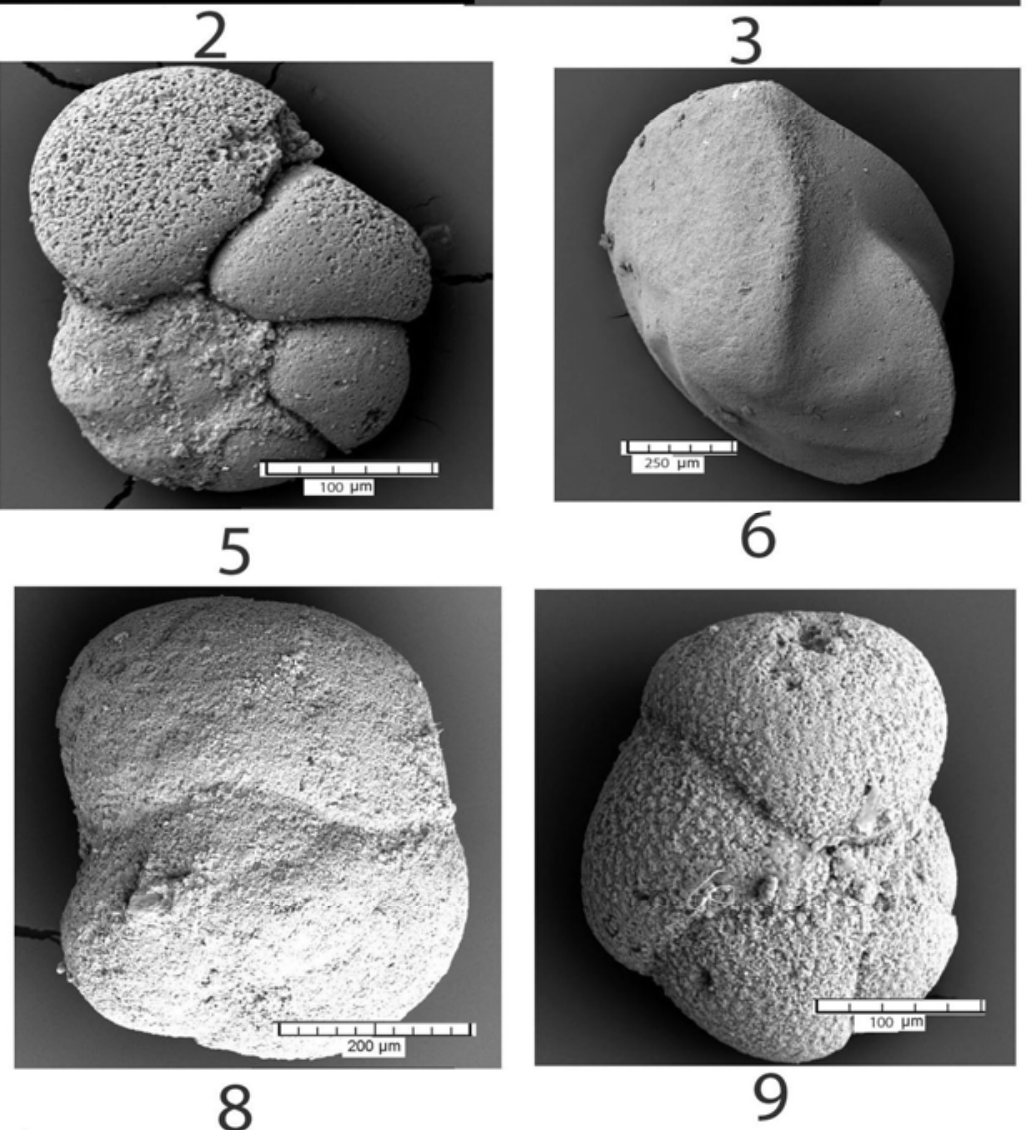

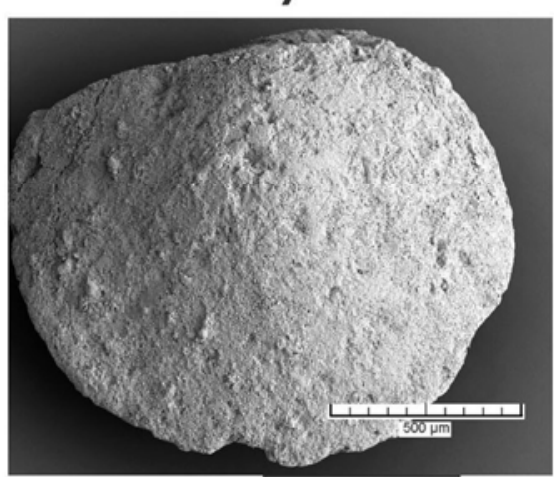

10

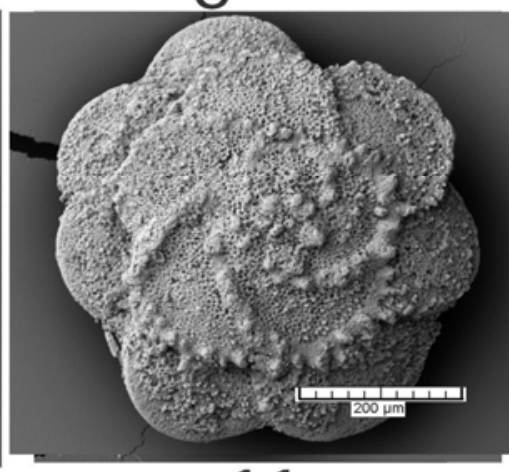

11

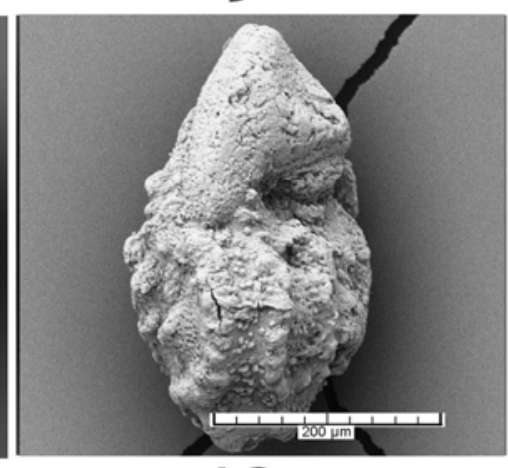

12 


\section{Plate -2}
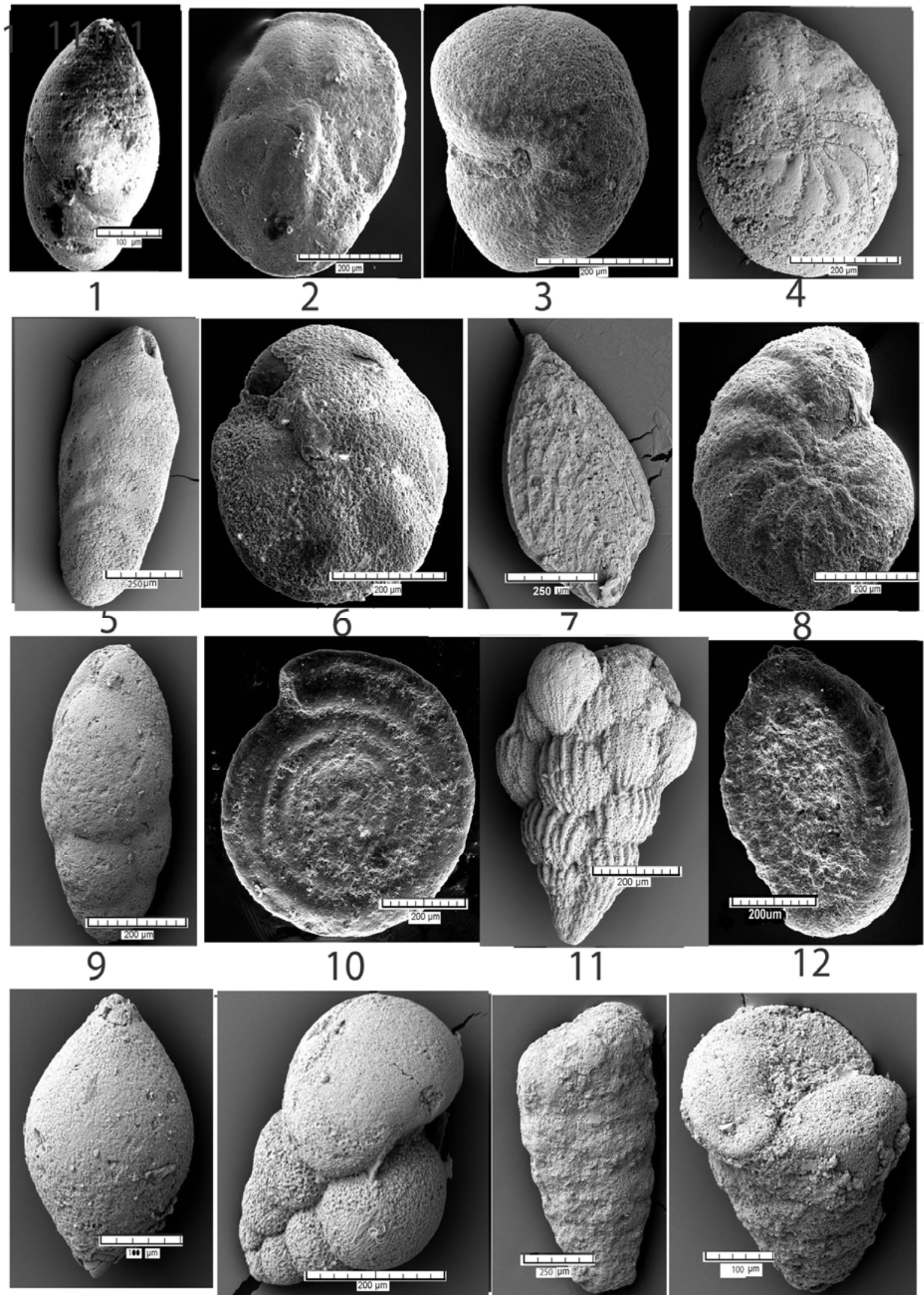

13

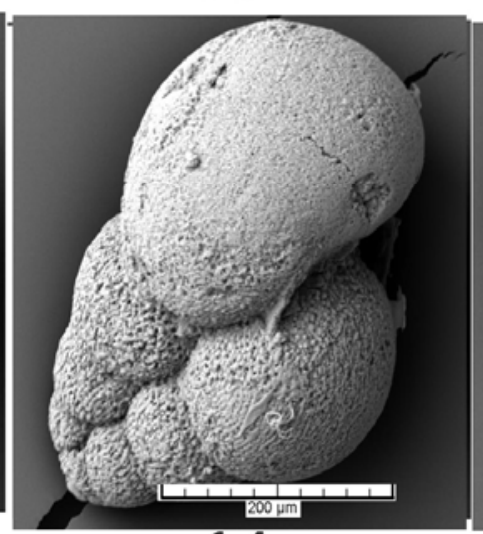

11

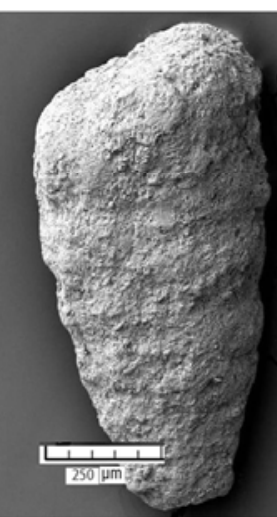

15

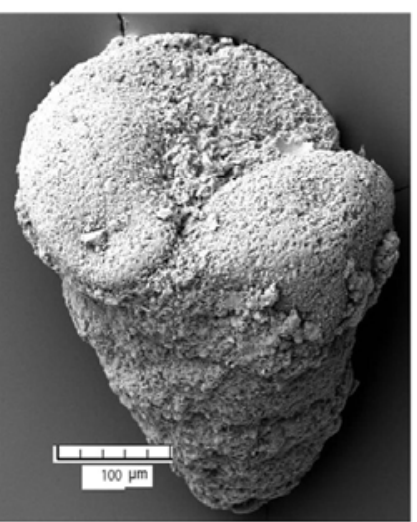

16 


\section{Plate- 3}

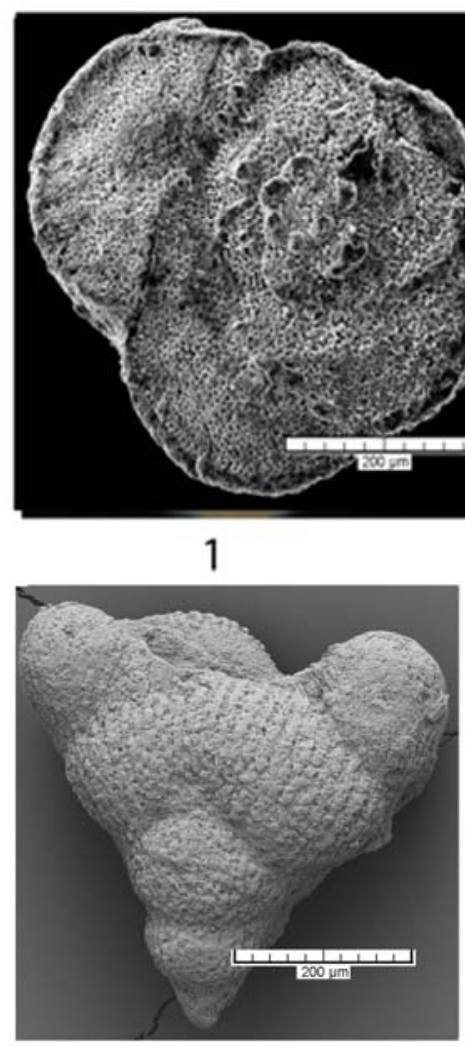

4
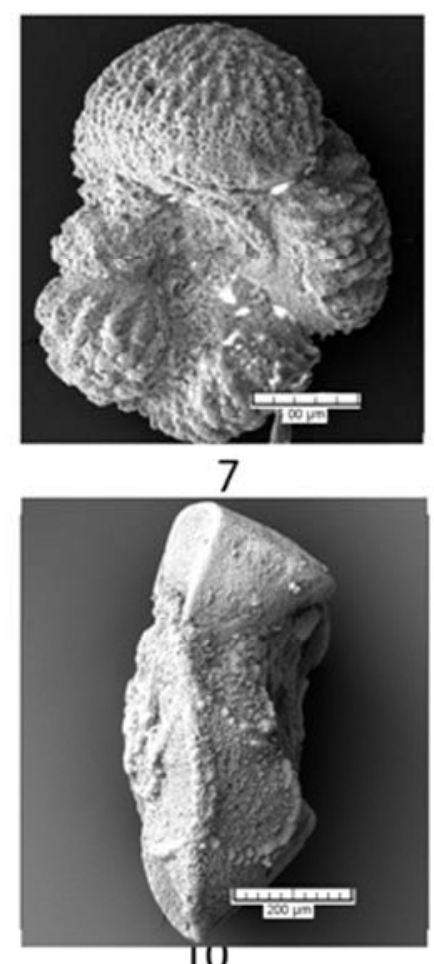

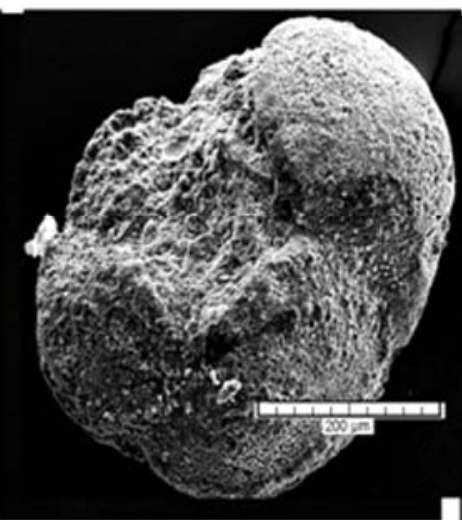

2

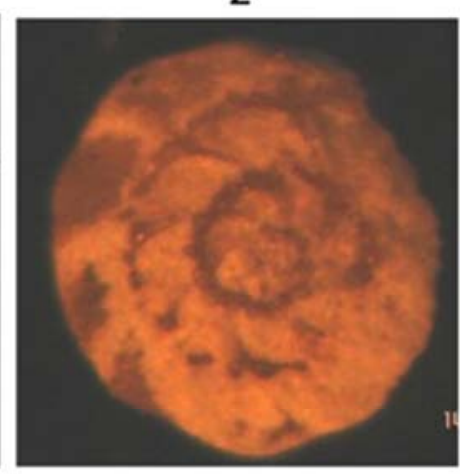

5

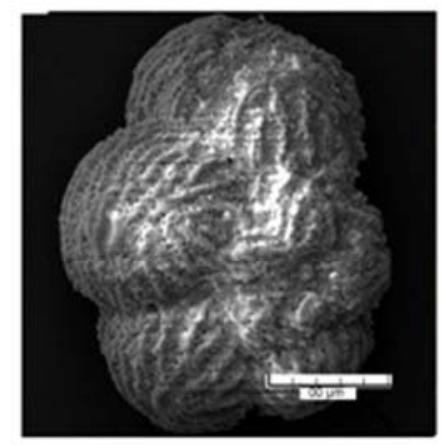

8

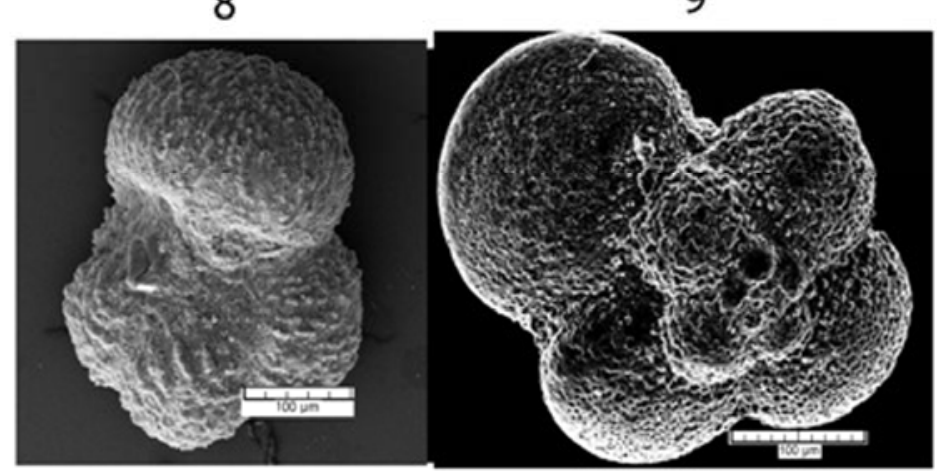

11

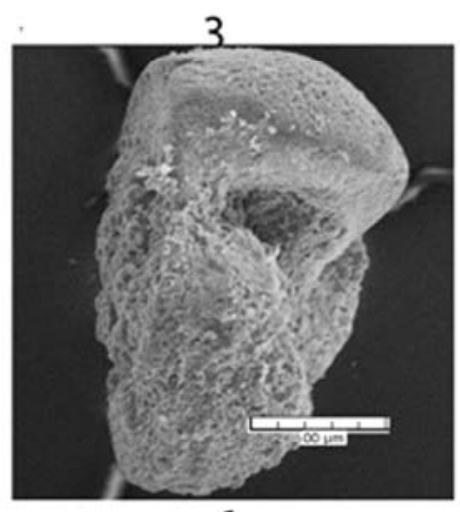

6

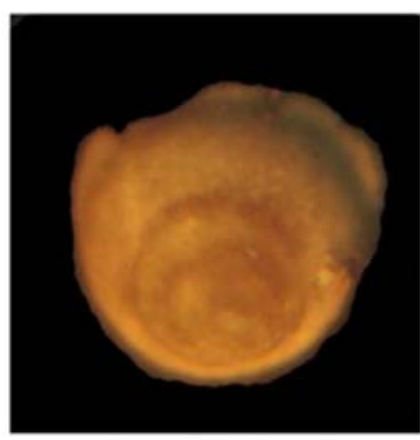

9

12 